\title{
EVALUATION OF COMBUSTION BEHAVIOUR FOR INDONESIAN LOW-RANK COALS TREATED HYDROTHERMALLY
}

\author{
EVALUASI PERILAKU PEMBAKARAN BATUBARA PERINGKAT \\ RENDAH INDONESIA YANG TELAH DIPROSES SECARA \\ HIDROTERMAL
}

\author{
DATIN FATIA UMAR ${ }^{a}$, MIKIO SHIMOJO ${ }^{b}$ and R. M. NENDARYONO MADIUTOMO \\ ${ }^{a}$ R\&D Centre for Mineral and Coal Technology \\ Jalan Jenderal Sudirman No. 623 Bandung, 40211 \\ e-mail: datinf@tekmira.esdm.go.id \\ b JGC Corporaton, 2-3-1, Minato Mirai, Nishi-ku, Yokohama, Japan
}

\begin{abstract}
Hydrothermal dewatering process has been made to produce dry-processed coals, which are comparable to bituminous coal. Two types of coals, i.e. low rank and high-rank coals. The low-rank coal came from West Papua while the high one was from Central Kalimantan. The behaviour of raw and processed coals were observed using thermogravimetry and differential scanning calorimetry techniques The change in chemical properties that are based on proximate, ultimate, calorific value and Fourier-transform infrared spectroscopy analyses are studied. Those are closely related to some combustion problems. This process was conducted in a laboratory scale using an autoclave with 5,000 $\mathrm{ml} / \mathrm{batch}$ in capacity at the temperature of 300 and $330^{\circ} \mathrm{C}$ for one hour. The results indicate that the processed coals generally have a better combustion behaviour than that of the raw coals. The processed coals have a lower reactivity than that of raw ones, due to the higher ignition temperature (Tig), char burnout temperature (Tbo) as the end of combustion and maximum combustion rate (Rmax) of processed coals. The processing temperature of the process was a slight effect on combustion behaviour. The process is very effective to improve the quality of low-rank coal, nonetheless to highrank coal, which has low moisture content and high calorific value, and the combustion behaviour of processed coals was not significantly changed.
\end{abstract}

Keywords: calorific value, high-rank coal, hydrothermal dewatering, ignition temperature, low-rank coal

\begin{abstract}
ABSTRAK
Pengawa-airan hidrotermal (hydrothermal dewatering) telah dilakukan untuk menghasilkan batubara dengan kualitas setara dengan batubara bituminus. Dua jenis batubara digunakan sebagai media percobaan, yaitu batubara peringkat rendah (2 percontoh batubara dari Papua Barat) dan batubara peringkat tinggi dari Kalimantan Tengah sebagai pembanding. Perilaku batubara wantah dan olahan diamati menggunakan tehnik thermogravimetry and differential scanning calorimetry. Perubahan sifat kimia berdasarkan hasil analisis proksimat, ultimat dan nilai kalor serta analisis Fourier-transform infrared spectroscopy yang terkait erat dengan masalah pembakaran juga dipelajari. Proses tersebut dilakukan pada skala laboratorium menggunakan otoklaf dengan kapasitas $5.000 \mathrm{ml} / \mathrm{batch}$ pada suhu 300 dan $330^{\circ} \mathrm{C}$ selama satu jam. Hasilnya menunjukkan bahwa batubara hasil olahan mempunyai sifat pembakaran lebih baik dibandingkan dengan sifat pembakaran batubara wantah. Batubara hasil olahan mempunyai reaktivitas lebih rendah daripada reaktivitas batubara wantah, karena suhu pembakaran awal (Tig), suhu pembakaran char sebagai akhir proses pembakaran (Tbo) dan laju pembakaran maksimum batubara (Rmax) hasil olahan lebih tinggi. Suhu yang diterapkan pada proses tersebut tidak begitu berpengaruh terhadap perilaku pembakaran. Proses ini sangat efektif untuk meningkatkan kualitas batubara peringkat rendah, namun untuk batubara peringkat tinggi yang memiliki kadar air rendah dan nilai kalor tinggi, perilaku pembakaran setelah mengalami proses tidak mengalami perubahan yang berarti.
\end{abstract}

Kata kunci: nilai kalor, batubara peringkat tinggi, pengawa-airan hidrotermal, suhu pembakaran, batubara peringkat rendah 


\section{INTRODUCTION}

Coal is the most abundant of fossil fuels. The world currently consumes over 7,800 million tonnes of coal which are used by a variety of sectors, including power generation, iron and steel production, cement manufacturing and as a liquid fuel (World Energy Council, 2016). The low-rank coals (LRCs) including lignite and subbituminous coals account for nearly half of the coal reserve worldwide (Yu et al., 2013). Indonesia is Southeast Asia's largest energy producer and consumer, and is also the world's largest exporter of steam coal. Other than being the most economical source of energy for electricity, coal mining industry plays an important role in supporting Indonesia's economy. Indonesian coal resources are amounted of 125.18 billion tonnes and coal reserves are amounted of 24.24 billion tonnes (Directorate of Program of Mineral and Coal Development, 2018). The coals are concentrated in two islands, Sumatra (50\%) and Kalimantan (49.5\%), the rest are in other islands. Indonesian coals are generally classified as low and medium rank coals of about $85.2 \% \quad(58.6 \%$ are lignite, $26.6 \%$ are sub-bituminous), high rank of bituminous coal of $14.4 \%$ and very high rank of anthracite of $0.4 \%$ (Pribadi, 2016).

The strategic planning of coal utilization is derived from the quality proportion of the resources in order to meet the market demand and domestic consumption for energy generation. LRCs are classified as low-grade fuel and are generally featured with low calorific value and high moisture content (25-65\%). The high moisture content, low calorific value and high spontaneous combustion tendency of LRCs are the major obstacles to their economic utilization. These obstacles significantly affect the economics of coal transportation, coal handling and the efficiency of coal utilization processes, such as combustion and gasification (Zhan et al., 2011). The advantages of LRCs include high reactivity, abundance, and low market price (Yu et al., 2013). However, LRCs have not been utilized as much as the high-rank coals (HRCs). In order to make the LRCs' characteristics comparable with those of HRCs, the material should be treated by an upgrading process prior to use to increase its energy density, promote its market value, and make it a transportable fuel. Upgrading the LRC by increasing its calorific value and decreasing its moisture content will be of great help in increasing its energy value (Katalambula and Gupta, 2009; Huang et al., 2016; Wu et al., 2017). The first step of the upgrading process is dewatering (Ge et al., 2015).

Hydrothermal dewatering (HTD) process, also known as hot water drying (HWD) technology, is a typical non-evaporative dewatering process. In the HTD process, the temperature is typically between 200 and $350^{\circ} \mathrm{C}$ (Favas and Jackson, 2003a; Mursito et al., 2010; Nonaka, Hirajima and Sasaki, 2011; Zhang et al., 2016), and the vessel pressure is generated autogenously to stop water from evaporation (Katalambula and Gupta, 2009). The HTD has several advantages over conventional dewatering methods, such as decarboxylation and irreversible dewatering, and has a comparatively superior product quality. A particular advantage of HTD is that most of the water is removed as a liquid, saving the energy that in some other drying techniques has to be used to evaporate the water. Moreover, much of the water-soluble inorganic material will be leached out, leading to a decrease of inorganic content in the dried coal (Favas and Jackson, 2003b; Liao et al., 2016). Because of these unique features, HTD has been extensively applied to improve LRCs characteristics (Mursito, Hirajima and Sasaki, 2011; Liu, Duan and Ma, 2015; Liu, Li and Duan, 2015; Wu et al., 2015).

Some researchers investigated the effect of HTD conditions on the treated coal properties (Racovalis, Hobday and Hodges, 2002; Favas and Jackson, 2003a; Sakaguchi et al., 2008), the properties of gas, liquid and liquid phase products (Mursito et al., 2010; Zhang et al., 2016), the effect of HTD treatment for LRC on its slurrying (Yu et al., 2012) and the disposal of wastewater produced from HTD (Racovalis, Hobday and Hodges, 2002). Ge et al. (2015) investigated three types of brown coals (with different coal ranks) produced in China and were processed them by HTD at different temperatures. The changes in the coal composition and microstructure of the LRC by HTD were investigated with emphasing on the improvement of coal rank and on the influence of HTD on the combustion characteristics of LRC. In the last paper (Umar, Daulay and Usui, 2004; Umar, Usui and Daulay, 2005), the effect of the HTD process, mainly the effect of processing temperature was studied and discussed by using Berau coal from East 
Kalimantan. The results indicate that the greatest moisture reduction was achieved at the processing temperature of $300^{\circ} \mathrm{C}$ and the processed coals have better combustion characteristics than that of the raw coals. Combustion characteristics have been conducted by using Shimadzu DTG-60 apparatus.

In previous research (Umar, 2016), the effect of HTD process on combustion characteristics was investigated by using some LRCs from Berau, Tabang, Samaranggau and Bunyu coals which were located in East Kalimantan and Banko coal in South Sumatra. The result shows that the processed coals have better combustion characteristics and lower tendency to self-combustion. In this paper, research was mainly aimed to understand the effect of HTD process on combustion behaviour. The initial and processed coals combustion behaviours were studied. The thermal analysis data can be applied not only to the characterization of different coals, but also to evaluate the combustion performance at high temperatures and heating rates. Two types of coals, LRCs (2 coal samples from West Papua) and HRC from Central Kalimantan as a comparison, were used to study the combustion behaviour of raw and processed coals using thermogravimetry and differential scanning calorimetry (TG-DSC) techniques. The change on chemical properties based on proximate, ultimate, calorific value and Fourier-transform infrared spectroscopy (FTIR) analyses, which are closely related to some combustion problems due to the HTD process were also studied.

\section{METHODOLOGY}

\section{Coal samples}

Two LRC coal samples from West Papua, namely SP and PB, and an HRC from Central Kalimantan, namely MD, were milled and sieved through $\pm 3 \mathrm{~mm}$ in size to be processed and sieved to pass $250 \mu \mathrm{m}$ (No. $60)$ sieve in order to determine the proximate, ultimate analyses and calorific value contents.

\section{Coal characterization}

The characterization of the raw and processed coals was carried out based on chemical, and combustion characteristics.
The proximate analysis covers the determination of moisture, ash, volatile matter, and the calculation of fixed carbon according to ASTM D.3173, D.3174, ISO 562 and ASTM D.3172, respectively. The ultimate analyses of carbon, hydrogen and nitrogen according to ASTM D. 5373, total sulphur and the calculation of oxygen according to ASTM D.4239 and ASTM D.3176, respectively, while calorific value content based on ASTM D.5865.

The main goal of the HTD process is to reduce the moisture content of the $L R C$, so that the calorific value increases. The parameter of dewatering was evaluated by the moisture content data of the raw and processed coals. The degree of dewatering (DD) is defined by the equation below:

$\mathrm{DD}: \frac{(\mathrm{M}) \text { raw coal }-(\mathrm{M}) \text { processed coal }}{(\mathrm{M}) \text { raw coal }} \times 100$

where: $\mathrm{M}$ is moisture content (\%) of the coals in air-dried basis.

\section{Hydrothermal Dewatering (HTD) Process}

The HTD process has been conducted in a laboratory scale by using an autoclave with $5,000 \mathrm{ml} /$ batch in capacity. The crushed coal (ca. $1500 \mathrm{~g}$ ) was mixed with water (30 wt\% solid) and the resulting slurry was put in an autoclave. A nitrogen atmosphere, with a pressure of $0.1 \mathrm{MPa}$ was maintained in the autoclave. The autoclave was heated to the desired temperature $\left(300\right.$ and $\left.330^{\circ} \mathrm{C}\right)$ at the rate of $3-4^{\circ} \mathrm{C} / \mathrm{min}$ and the time was maintained for one hour (Umar, Usui and Daulay, 2005). The mixture was stirred at 75 rpm during the entire process. After the autoclave was cooled down to ambient temperature, the processed coal was taken out and was washed with water. The coal sample was filtered, dried and stored in a sealed container for further tests. The stored processed coals were then marked in accordance with the applied temperature, i.e. SP 300 for SP coal processed with HTD at $300^{\circ} \mathrm{C}$ and SP330 for SP processed at $330^{\circ} \mathrm{C}$. Likewise to processed $\mathrm{PB}$ and $\mathrm{MD}$ to be PB300, PB330, MD 300 and MD 330.

\section{Fourier transform infrared spectroscopy}

A Fourier transform infrared spectrometer (FTIR) of Shimadzu IR Prestige-21 in the resolution of $1 \mathrm{~cm}^{-1}$ was used to study the 
change in chemical structure caused by the HTD process. Sample preparation in the FTIR test was done by the $\mathrm{KBr}$ pellets method, and reference material for calibration was pure $\mathrm{KBr}$ pellet itself (Mahidin et al., 2003). The pellet used for the test was prepared from a mixture of $1 \mathrm{mg}$ coal and $100 \mathrm{mg} \mathrm{KBr}$ (Zhang et al., 2016). The measuring region ranging from 4000 to $400 \mathrm{~cm} 1$, which are $3000-2700 \mathrm{~cm}^{-1}$ and $1800-1500 \mathrm{~cm}^{-1}$ were assigned to the aliphatic hydrogen (C-H functional group) and oxygen-containing structures $(\mathrm{C}=\mathrm{O}$ functional group), respectively. For each spectrum, 32 scans were accumulated. The intensities of the selected bands in the FTIR absorbance spectra were evaluated by the baseline method in order to obtain the concentration of the functional groups of C$\mathrm{H}$ and $\mathrm{C}=\mathrm{O}$. The evaluated concentrations were then converted as relative absorbance of the coal samples. The FTIR spectra were identified based on the FTIR reference spectra available on the World Wide as shown in Figure 1 (Scaccia, 2013).

\section{Thermogravimetry-differential scanning calorimetry (TG-DSC)}

TG-DSC and their first derivatives of DTG and DDSC (dTG/dt and dDSC/dt), respectively, monitor the relative mass loss, the rate of mass loss and the relative heat flow and rate of heat flow in the air as a function of temperature. This method has been demonstrated to be a very valuable technique for studying the combustion of a wide range of solid samples (Marinov et al., 2010; Sahu et al., 2010; Scaccia, 2013).

The effects of HTD process on its thermal and combustion behaviours were studied using a thermogravimetric analyzer of LINSEIS High-Pressure STA (Simultaneous Thermal Analysis) TG-DTA/DSC (thermogravimetry/differential thermal analysis/differential scanning calorimetry). The sample with the weight of about 12-20 $\mathrm{mg}$ was placed in an alumina cell at an airflow rate of $25 \mathrm{ml} / \mathrm{min}$ and a heating rate of $10^{\circ} \mathrm{C} / \mathrm{min}$ (Cheng et al., 2011).

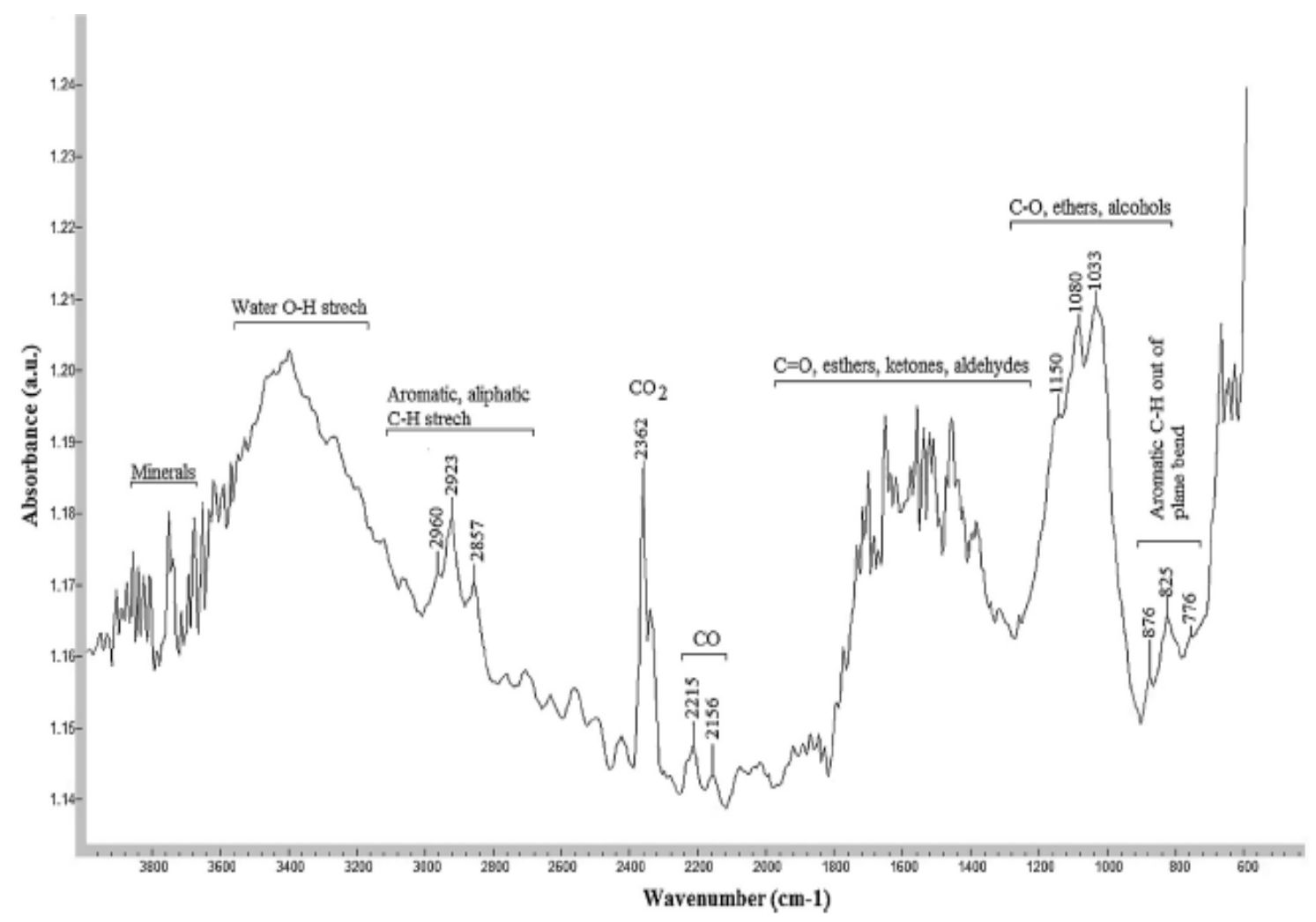

Figure 1. FTIR Spectra of coal (Scaccia, 2013) 
The maximum experimental temperature was $800^{\circ} \mathrm{C}$. The weight loss of the sample and the rate of the weight loss were recorded continuously under dynamic conditions as a function of time or temperature, and all the experiments were performed at atmospheric pressure, under an inert air atmosphere. Various characteristic parameters from combustion profiles can be obtained. They are defined as follow (Marinov et al., 2010):

Tig $(\circ \mathrm{C}) \quad$ : ignition temperature at which the weight loss curve (TGA) of the coal combustion is departed from the baseline

Tmax ( $\left.{ }^{\circ} \mathrm{C}\right)$ : peak temperature of maximum heat flow (DSC);

Tbo $\left({ }^{\circ} \mathrm{C}\right) \quad$ : end of combustion temperature at which the rate of heat flow is zero (DDSC);

$\operatorname{Rmax}(\mathrm{mg} / \mathrm{s})$ : maximum weight loss rate (DTG):
The determination of the combustion parameters as above from the thermogram is illustrated in Figure 2.

\section{RESULT AND DISCUSSIONS}

\section{Effect of HTD on Coal composition}

Chemical compositions of raw and processed coals based on proximate, ultimate and calorific value analyses are shown in Table 1.

The moisture contents of both LRCs were significantly reduced by the HTD process, dropping from $19.84 \%$ in SP to $10.02 \%$ in $\mathrm{HTD}$ at $300^{\circ} \mathrm{C}$ and to be $8.75 \%$ in HTD at $330^{\circ} \mathrm{C}$. Whilst the PB dropped from $20.64 \%$ to $9.89 \%$ and $6.89 \%$ at $\operatorname{HTD} 300^{\circ} \mathrm{C}$ and $330^{\circ} \mathrm{C}$, respectively. Zhang et al. (2016) also claimed that the moisture in raw coal was irreversibly removed and the water holding capacity of the coal was significantly reduced by the HTD process.

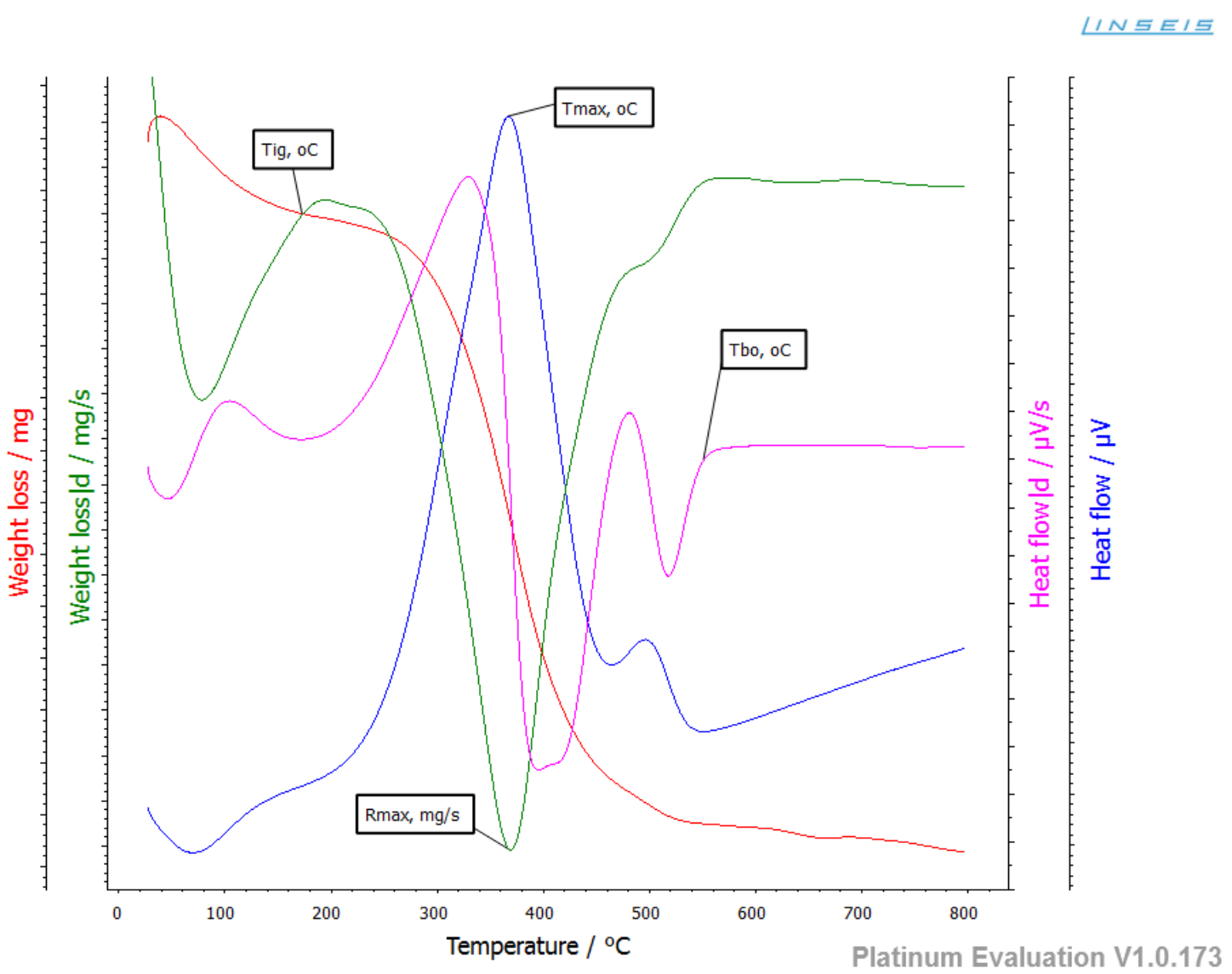

Figure 2. Combustion parameters from the TG-DSC tests (Marinov et al., 2010) 
Table 1. Proximate, ultimate and calorific value of coals

\begin{tabular}{|c|c|c|c|c|c|c|c|c|c|}
\hline Analysis & $\mathrm{SP}$ & SP 300 & SP 330 & $\mathrm{~PB}$ & PB 300 & PB 330 & MD & MD 300 & MD 330 \\
\hline $\begin{array}{l}\text { Calorific value, cal/g } \\
\text { air dried basis }\end{array}$ & 4675 & 5800 & 6038 & 4595 & 5644 & 6131 & 6371 & 6564 & 6956 \\
\hline \multicolumn{10}{|c|}{ Proximate, wt\% air dried basis } \\
\hline Inherent Moisture & 19.84 & 10.02 & 8.75 & 20.64 & 9.89 & 6.89 & 8.57 & 6.84 & 4.41 \\
\hline Ash & 4.95 & 7.93 & 6.74 & 5.31 & 8.24 & 8.19 & 4.50 & 4.77 & 4.58 \\
\hline Volatile matter & 39.70 & 38.70 & 37.51 & 39.42 & 38.78 & 38.72 & 42.32 & 40.26 & 40.14 \\
\hline Fixed carbon & 35.51 & 44.62 & 45.73 & 34.63 & 43.09 & 46.20 & 44.61 & 48.13 & 50.87 \\
\hline \multicolumn{10}{|c|}{ Degree of dewatering, \% } \\
\hline & - & 49.46 & 55.90 & - & 52.08 & 66.62 & - & 20.19 & 48.54 \\
\hline \multicolumn{10}{|c|}{ Ultimate, wt\% dry ash free basis } \\
\hline Carbon & 67.89 & 75.10 & 75.43 & 68.52 & 73.79 & 76.19 & 76.56 & 76.72 & 79.71 \\
\hline Hydrogen & 7.86 & 6.29 & 6.27 & 7.81 & 6.38 & 6.09 & 6.68 & 6.40 & 6.18 \\
\hline Nitrogen & 1.55 & 1.82 & 1.77 & 1.49 & 1.80 & 1.84 & 1.44 & 1.38 & 1.47 \\
\hline Sulphur & 0.42 & 0.46 & 0.44 & 0.43 & 0.46 & 0.48 & 0.37 & 0.34 & 0.33 \\
\hline Oxygen & 22.27 & 16.33 & 16.08 & 21.76 & 17.58 & 15.40 & 14.95 & 15.17 & 12.32 \\
\hline \multicolumn{10}{|l|}{ Atomic ratio } \\
\hline $\mathrm{O} / \mathrm{C}$ & 0.33 & 0.22 & 0.21 & 0.32 & 0.24 & 0.20 & 0.19 & 0.19 & 0.15 \\
\hline $\mathrm{H} / \mathrm{C}$ & 0.12 & 0.08 & 0.08 & 0.11 & 0.09 & 0.08 & 0.09 & 0.08 & 0.08 \\
\hline
\end{tabular}

The reducing of moisture content was also obtained by Wu et al. (2015) in their research using XiMeng lignite. With increasing HTD temperature, the moisture contents were further decreased. These results were in accordance with the last result (Umar, Usui and Daulay, 2005; Umar, 2016). Different from the LRCs of SP and $\mathrm{PB}$, the decreasing of the moisture content of the processed HRC of MD was insignificant. It was reflected by the degree of dewatering (DD) value. The DD of SP was $49.46 \%$ and $55.90 \%$, while PB was $52.08 \%$ and $66.62 \%$, which were processed at a temperature of $300^{\circ} \mathrm{C}$ and $300^{\circ} \mathrm{C}$, respectively. Whereas the $\mathrm{DD}$ of $\mathrm{MD}$ was only $20.19 \%$ which was processed at $300^{\circ} \mathrm{C}$ and $48.54 \%$ at $330^{\circ} \mathrm{C}$. It means that the HTD process is effective to upgrade the LRC, but not for the HRC which originally has a low moisture content. The form of moisture in the LRC is different from the moisture content in the HRC. Water-coal interactions are very complicated and the water existed in different forms. The coalification process was accompanied by the elimination of water due to chemical changes associated with the coalification process and the physical consolidation of the coal deposit. LRC contains a number of oxygen functional groups resulting in a material with hydrophilicity, and this is the primary reason for their water content being as high as 30-65 wt.\% (Yu et al., 2012). The behaviour of water in coal depends on many factors such as intermolecular hydrogen bonding, coordination of water molecules to cations, having short-range coherence in their structure, and whether they are in the form of small clusters (Yu et al., 2013). The decreasing in moisture contents of the processed coals is followed by the increasing of calorific values. It can be seen that temperature affects the calorific value.

The HTD process is proven to upgrade the LRC by the proximate analysis (increase of fixed carbon and decrease of volatile matter contents) and the ultimate analysis (increase of carbon and decrease of oxygen contents), as shown in Table 1. The volatile matter and oxygen contents decreased with the increase of temperature due to the decomposition of oxygen functional groups (Mursito, Hirajima and Sasaki, 2011; Yu, Liu and Cen, 2014). So that the ratios of oxygen to carbon $(\mathrm{O} / \mathrm{C})$ and hydrogen to carbon $(\mathrm{H} / \mathrm{C})$ of the samples were decreased after the HTD. The temperature of HTD process was highly affected on the decreasing of $\mathrm{O} / \mathrm{C}$ and $\mathrm{H} / \mathrm{C}$ ratios. This result is in line with the researches that have been conducted by other researchers (Yu, Liu and Cen, 2014; Ge et al., 2015; Wu et al., 2015; Liao et al., 2016). According to those ratios, the treated LRCs have O/C ratio close to the HRC, whereas $\mathrm{H} / \mathrm{C}$ ratio was equal, which means the upgrading of coal.

\section{Effect of HTD on functional groups}

The FTIR spectra obtained for the raw and processed coals are presented in Figure 3. The selected ranges of $3000-2750 \mathrm{~cm}^{-1}$ and 
$1800-1500 \mathrm{~cm}^{-1}$ correspond to the structure of aliphatic hydrogen (C-H functional group) and the oxygen-containing structures $(\mathrm{C}=\mathrm{O}$ functional group), respectively. A selected zone of $3000-2750 \mathrm{~cm}^{-1}$ is deconvoluted into five peaks, 2965, 2920, 2895, 2870, and 2850 $\mathrm{cm}^{-1}$, which are assigned to $\mathrm{RCH}_{3}$ (asym.), $\mathrm{R}_{2} \mathrm{CH}_{2}$ (asym.), $\mathrm{R}_{3} \mathrm{CH}, \mathrm{RCH}_{3}$ (sym.), and $\mathrm{R}_{2} \mathrm{CH}_{2}$ (sym.), respectively. Also, a selected zone of $1850-1500 \mathrm{~cm}^{-1}$ is deconvoluted into eight peaks, 1770, 1710, 1700, 1655, 1615, 1580,1560 , and $1540 \mathrm{~cm}^{-1}$, which are assigned to esters and aliphatic $\mathrm{COOH}$, aromatic $\mathrm{COOH}$, aromatic $\mathrm{COOH}$ and conjugated $\mathrm{C}=\mathrm{O}$, highly conjugated $\mathrm{C}=\mathrm{O}$, aromatic $\mathrm{C}=\mathrm{C}$, and carboxylate groups COO-, respectively (Ohki et al., 1999; Liu, Li and Duan, 2015).

From Figure 3, it can be seen that the FTIR spectra of the processed coals in the selected zone were reduced compared to that of the raw coal. The peaks of the FTIR spectra decreased with the increasing of processing temperature at the selected zone. The selected zone between 3000 and $2800 \mathrm{~cm}^{-1}$, a dominant peak appears at $2920-2850 \mathrm{~cm}^{-1}$, which corresponds to aliphatic $\mathrm{C}-\mathrm{H}$ ( $\mathrm{Liu}, \mathrm{Li}$ and Duan, 2015), shows that all of the processed coals slightly decreased compare to that of the raw coals. The peaks of processed SP and PB coals at $330^{\circ} \mathrm{C}$ of SP 330 and PB 330, show that the aliphatic $\mathrm{C}-\mathrm{H}$ were almost completely lost. The FTIR spectra at $1760-1680 \mathrm{~cm}^{-1}$, which corresponds to carboxyl groups also decreased with the increasing of HTD processing temperature. This result is slightly different to the study performed by Zhang et al. (2016), about coal aromaticity of raw and HTD treated coals. They found that in-band between 3000 and $2800 \mathrm{~cm}^{-1}$, showing no obvious change between the raw coal and the HTD treated coals. Whilst at the stretching vibration of carboxyl at 1760-1680 $\mathrm{cm}^{-1}$ is progressively weakened in the spectra of the samples treated under increasing temperature. The difference between Zhang et al. (2016) results and this results is most likely caused by the moisture content of the raw coal. It is well known that the absorbance spectra is relative compared to the raw coal.

The FTIR spectra shows that the relative abundances of $\mathrm{C}-\mathrm{H}$ and $\mathrm{C}=\mathrm{O}$ groups, which correspond to the stretching vibrations aliphatic $\mathrm{CHx}$ and carboxyl groups, respectively, which are closely related to the moisture content of coal (Figure 4). The figure shows that the relative abundances of $\mathrm{C}-\mathrm{H}$ and $\mathrm{C}=\mathrm{O}$ groups of all of the processed coals were decreased compared to that of the raw coals. When the temperature was increased from $300^{\circ} \mathrm{C}$ up to $330^{\circ} \mathrm{C}$, the relative abundances of the $\mathrm{C}=\mathrm{O}$ and $\mathrm{C}-\mathrm{H}$ groups were decreased due to the removal of water content. This results are consistent with the studies, which were conducted by Liu, Li and Duan (2015), Mursito et al. (2010) and Zhang et al. (2016).
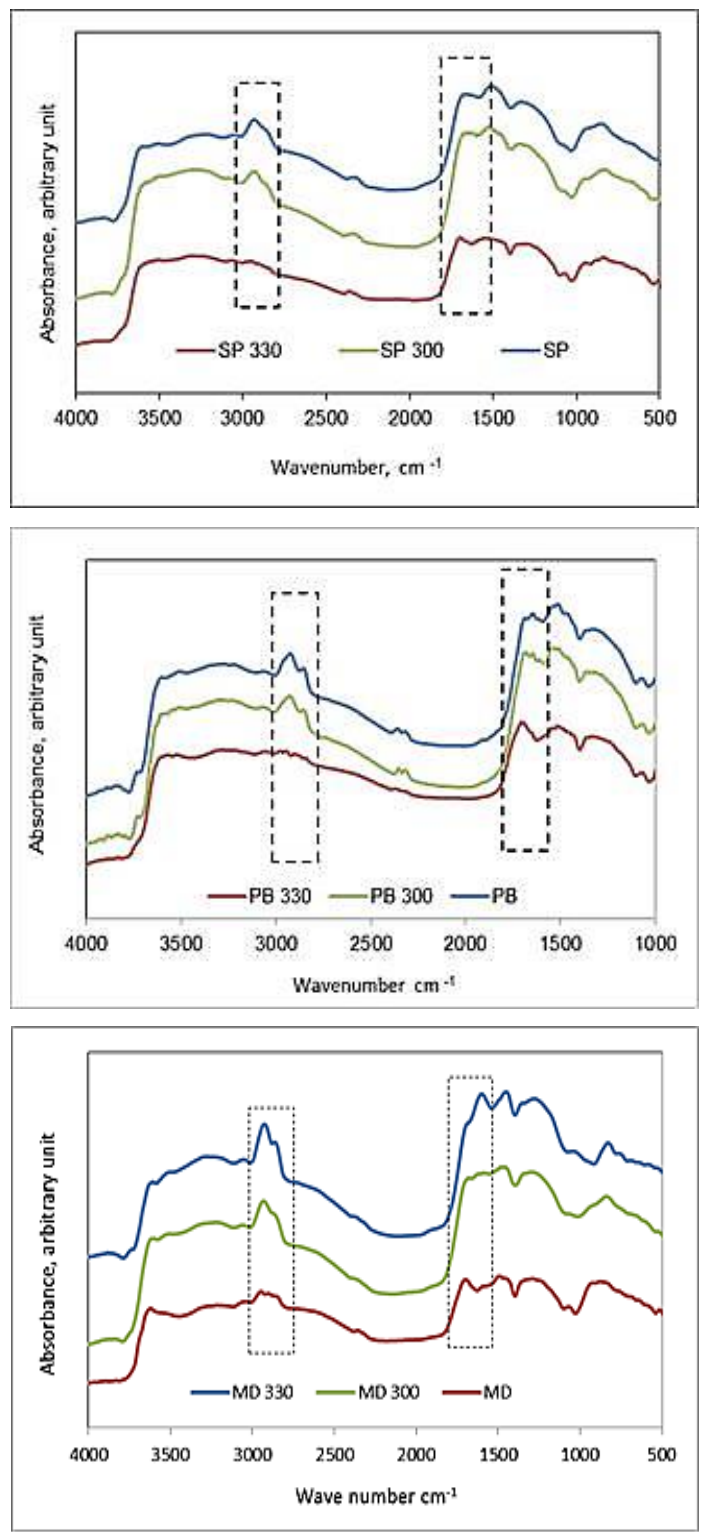

Figure 3. FTIR spectra of raw and processed coals 

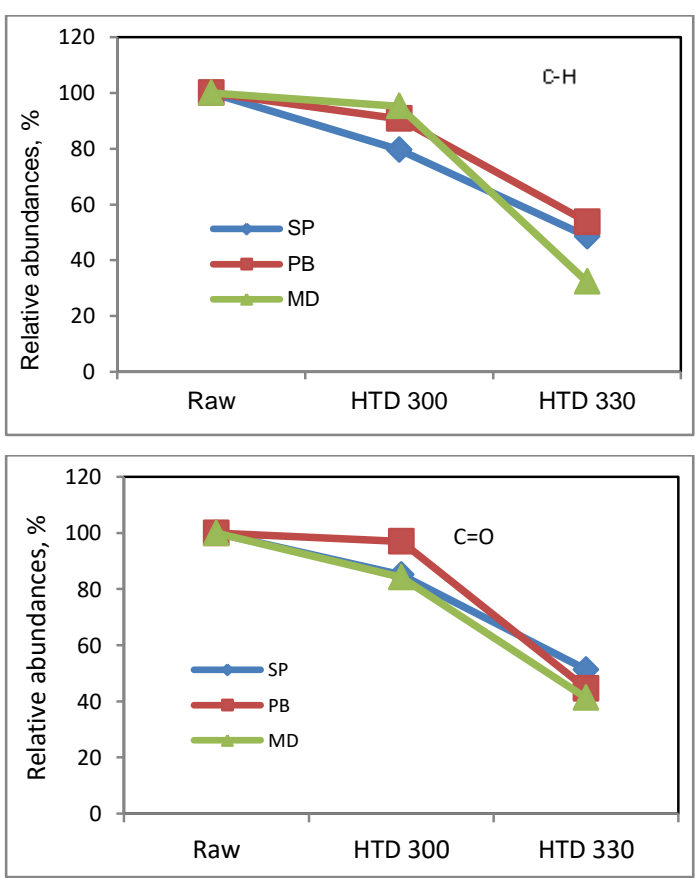

Figure 4. Relative content of $\mathrm{C}-\mathrm{H}$ and $\mathrm{C}=\mathrm{O}$ in the raw and processed coals

\section{Effect of HTD on TG/DSC profiles}

Figure 5 shows the TG, DSC and their first derivatives (DTG and DDSC) curves. It can be seen that the weight loss of SP and PB raw coals at a temperature of about $50-100^{\circ} \mathrm{C}$ sharply decreased due to the high moisture content. Whilst the MD, SP, and PB processed coals, the profile of TGA curve at that temperature was decreased slightly. These profiles were in line with the moisture content of the coals, as shown in Table 1.

The TG profiles of all investigated coals have a gradual and slight weight loss before $270^{\circ} \mathrm{C}$ and then a great weight loss till the burn out of the coal. Correspondingly, DTG curves of SP and PB present 2 peaks. The first peaks with tiny peaks were the weight loss rate, corresponding to moisture content at a temperature of $110-120^{\circ} \mathrm{C}$. The processed coals and high-rank coal of MD the peak of weight loss, which was assigned as moisture released were not significant due to the low moisture content. The peaks at a temperature of about $200-220^{\circ} \mathrm{C}$ were mainly attributed to oxygen chemisorptions accompanied with the formation of surface oxygen-containing complexes, while the weight loss at the high temperatures is obviously due to intensive coal combustion that denoted as maximum combustion rate (Rmax).
DSC profiles visualize the evolution of heat flow with elevated temperatures. The first part of DSC curves corresponds to a global endothermic process, which is a result of heat adsorption (endothermic) and oxidation reactions (exothermic). As can be seen in Figure 5, the first peak of DSC curves (heating loss, $\mu \mathrm{v}$ ) corresponds to a global endothermic process, which was appeared at about $100^{\circ} \mathrm{C}$, as a result of water vaporization. In the case of SP and PB coals, the peaks were higher compared with those of $\mathrm{MD}$ and processed coals due to higher moisture content. The second peaks show the highest, exhibiting exothermic events during the entire combustion test at the temperatures higher than $350^{\circ} \mathrm{C}$. The DSC peaks of processed coals were higher than that of the raw coals. The peaks increased by increasing the processing temperature. The increase of the peak in processed coals shows that a greater heat released during combustion was taking place. Therefore, the calorific value of processed coals were higher than those of the raw coals. From the DDSC curve, it is possible to determine the end of combustion (Tbo). This is in correspondence to the temperature when the rate of heat flow is zero (Marinov et al., 2010).

Several parameters derived from TG-DSC analysis are summarized in Table 2. The ignition (Tig) is an important preliminary step in the coal combustion process due to its influence on the formation and emission of pollutants, flame stability and flame extinction (Sahu et al., 2010). From Table 2 it can be seen that the Tig value of HRC of MD and processed LRCs and HRC were higher than those of the LRSc of SP and PB. The Tig was increased by increasing the temperature. The increase of Tig is ascribed to the decreased of the volatile matter (Solomon et al., 1991). The Tig value of the whole coal samples are in line with the result of volatile matter content as shown in Table 1.

The peak temperature of the maximum weight loss rate (Tmax) is considered the most important feature of the DTG profiles. The Tmax relates to the coal reactivity. Coals with lower Tmax are indicative of more reactive and can generally be ignited and burned more easily. Such coals would be expected to burn more completely in the lower part of a boifer furnace, while coals exhibiting high Tmax burn relatively slowly and would require longer residence times or higher 
temperatures for complete combustion (Norton, 1993). It can be seen that the Tmax of the SP and MD coals, processed at a temperature of $300^{\circ} \mathrm{C}$, decreased (SP 300 and
MD 300) and then increased at the processing temperature of $330^{\circ} \mathrm{C}$, while at the $\mathrm{PB}$ coal, the Tmax decreased with the increase of processing temperature.
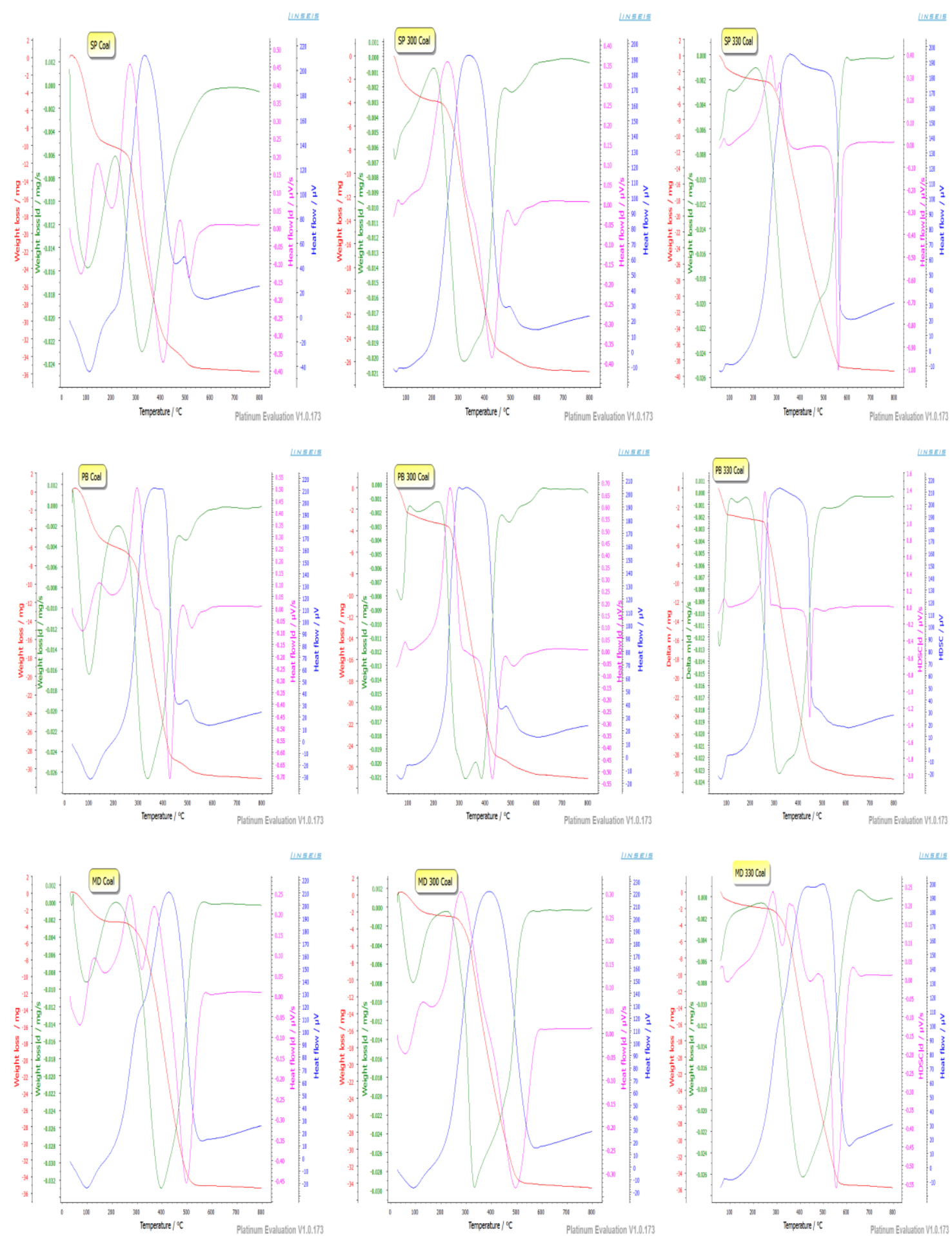

Figure 5. Thermogram of TG-DSC and their derivatives of raw and processed coals 
Table 2. Combustion parameter of raw and processed coals

\begin{tabular}{lcccc}
\hline & Tig, ${ }^{\circ} \mathrm{C}$ & $\begin{array}{c}\text { Tmax, } \\
{ }^{\circ} \mathrm{C}\end{array}$ & $\begin{array}{c}\text { Tbo, } \\
{ }^{\circ} \mathrm{C}\end{array}$ & $\begin{array}{c}\text { Rmax, } \\
\mathrm{mg} / \mathrm{s}\end{array}$ \\
\hline SP & 194.7 & 322.4 & 580.5 & 0.021 \\
SP 300 & 217.9 & 316.3 & 593.7 & 0.022 \\
SP 330 & 244.3 & 365.7 & 615.6 & 0.025 \\
\hline PB & 190.7 & 335.0 & 571.7 & 0.016 \\
PB 300 & 206.9 & 321.1 & 606.7 & 0.022 \\
PB 330 & 231.5 & 317.3 & 608.6 & 0.024 \\
\hline MD & 253.5 & 397.0 & 573.8 & 0.028 \\
MD 300 & 259.4 & 332.1 & 580.1 & 0.029 \\
MD 330 & 261.6 & 412.1 & 609.6 & 0.029 \\
\hline
\end{tabular}

The Rmax indicates the maximum combustion rate. All of the processed coals were slightly higher than that of those raw coals. The Rmax of the SP 300 and SP 330, was 0.021 and $0.025 \mathrm{mg} / \mathrm{s}$, respectively, which was initially $0.020 \mathrm{mg} / \mathrm{s}$, while the PB 300 and PB 330 the Rmax was 0.022 and $0.024 \mathrm{mg} / \mathrm{s}$. Compared to that of HRC, the Rmax of MD and processed of MD 300 and MD 330 was higher than those of SP and PB processed coals. It can be expressed that coals with the high Rmax were easier to be burnt due to their high calorific value and less moisture content (Song et al., 2017). The lower Rmax of the processed coals was consistent with the calorific value, moisture and carbon contents of the coals, as shown in Table 1. It can be seen that the carbon content and calorific value of the MD coal were higher but the moisture content was lower than those of the SP and PB processed coals.

The Tbo reflects the char characteristic. It is also possible to determine the end of combustion. This corresponds with the temperature when the rate of heat flow is zero. The Tbo of all of the processed coals was higher than that of the raw coals. The Tbo increased linearly with increasing the processing temperature. This observation is due to increasing the amounts of fixed carbon of treated coal samples (Table 1), which involves the necessities of longer combustible time to burn up more amounts of carbonaceous matter (Marinov et al., 2010).

The MD coal, which is categorized as HRC, has better combustion characteristics than that of LRC. The difference of the coals was caused by the differences in the composition and content of combustible gases and the initial evolving temperature since the ignition for HRC was controlled by the volatile content. However, it was difficult to cite the general comparison between the HRC and LRC, because the ignition of the LRC was largely influenced by the reactivity of the oxygen. In general, those coals with high weight loss in the low-temperature range can be considered to be easy to ignite and burn out (Khatami and Levendis, 2016).

\section{CONCLUSIONS}

The HTD process produced coal with better combustion behaviour compared to that of the raw coal. The processed coals have higher carbon content and calorific value, and lower content of moisture. According to the FTIR analysis, the processed coals have lower $\mathrm{C}-\mathrm{H}$ and $\mathrm{C}=\mathrm{O}$ functional groups compared to those of raw coals. From the TG-DSC analyses and their first derivatives of DTG and DDSC, some combustion parameters were obtained. The processed coals have higher ignition temperature (Tig), char burnout temperature (Tbo) and maximum combustion rate (Rmax), while the peak temperature of maximum weight loss rate (Tmax) of processed coals was lower than that of the raw coals. The processing temperature of 300 and $330^{\circ} \mathrm{C}$ of HTD was slightly effected on combustion behaviour. The HTD process is very effective to improve the quality of LRC, nonetheless for HRC that has low moisture content and high calorific value, the combustion behaviour of processed coals was not significantly changed.

\section{ACKNOWLEDGEMENTS}

The authors gratefully acknowledge the R\&D Centre for Mineral and Coal Technology (tekMIRA) and JGC Corp, Japan for a collaboration to conduct this research. Thanks also to the staff at the coal laboratory of RDCMCT for their assistance during the laboratory tests. 


\section{REFERENCES}

Cheng, Q., Wang, J., Singh, K. and Zondlo, J. (2011) "TGA-FTIR analysis of woody biomass and coal for energy production," in Proc. of FPS Conference. Oregon.

Directorate of Program of Mineral and Coal Development (2018) Indonesia's Country Report, Presented on the 16th AFOC Council Meeting. Vientiane, Lao PDR.

Favas, G. and Jackson, W. R. (2003a) "Hydrothermal dewatering of lower rank coals. 1. Effects of process conditions on the properties of dried product," Fuel, 82(1), pp. 53-57. doi: 10.1016/S00162361(02)00192-8.

Favas, G. and Jackson, W. R. (2003b) "Hydrothermal dewatering of lower rank coals. 2. Effects of coal characteristics for a range of Australian and international coals," Fuel, 82(1), pp. 59-69. doi: 10.1016/S0016-2361(02)00191-6.

Ge, L., Zhang, Y., Xu, C., Wang, Z., Zhou, J. and Cen, K. (2015) "Influence of the hydrothermal dewatering on the combustion characteristics of Chinese low-rank coals," Applied Thermal Engineering, 90, pp. 174-181. doi: 10.1016/j.applthermaleng.2015.07.015.

Huang, Q., Li, S., Li, G., Zhao, Y. and Yao, Q. (2016) "Reduction of fine particulate matter by blending lignite with semi-char in a down-fired pulverized coal combustor," Fuel, 181, pp. 1162-1169. doi: 10.1016/j.fuel.2016.04.026.

Katalambula, H. and Gupta, R. (2009) "Lowgrade coals: A review of some prospective upgrading technologies," Energy \& Fuels, 23(7), pp. 3392-3405. doi: 10.1021/ef801140t.

Khatami, R. and Levendis, Y. A. (2016) "An overview of coal rank influence on ignition and combustion phenomena at the particle level," Combustion and Flame, 164, pp. 22-34. doi: 10.1016/j.combustflame.2015.10.031.

Liao, J., Fei, Y., Marshall, M., Chaffee, A. L. and Chang, L. (2016) "Hydrothermal dewatering of a Chinese lignite and properties of the solid products," Fuel, 180 , pp. 473-480. doi: 10.1016/j.fuel.2016.04.027.
Liu, M., Duan, Y. and Ma, G. (2015) "The effect of organic solvent thermal treatment on the physicochemical properties of lignite," Asia-Pacific Journal of Chemical Engineering, 10(5), pp. 724-733. doi: 10.1002/apj.1910.

Liu, M., Li, J. and Duan, Y. (2015) "Effects of solvent thermal treatment on the functional groups transformation and pyrolysis kinetics of Indonesian lignite," Energy Conversion and Management, 103, pp. 66-72. doi: 10.1016/j.enconman.2015.06.047.

Mahidin, Ogaki, Y., Usui, H. and Okuma, O. (2003) "The advantages of vacuum-treatment in the thermal upgrading of low-rank coals on the improvement of dewatering and devolatilization," Fuel Processing Technology, 84(1-3), pp. 147-160. doi: 10.1016/S0378-3820(03)00052-3.

Marinov, S. P., Gonsalvesh, L., Stefanova, M., Yperman, J., Carleer, R., Reggers, G., Yürüm, Y., Groudeva, V. and Gadjanov, P. (2010) "Combustion behaviour of some biodesulphurized coals assessed by TGA/DTA," Thermochimica Acta, 497(1-2), pp. 46-51.

doi: 10.1016/j.tca.2009.08.012.

Mursito, A. T., Hirajima, T. and Sasaki, K. (2011) "Alkaline hydrothermal de-ashing and desulfurization of low quality coal and its application to hydrogen-rich gas generation," Energy Conversion and Management, 52(1), pp. 762-769. doi: 10.1016/j.enconman.2010.08.001

Mursito, A. T., Hirajima, T., Sasaki, K. and Kumagai, S. (2010) "The effect of hydrothermal dewatering of Pontianak tropical peat on organics in wastewater and gaseous products," Fuel, 89(12), pp. 3934-3942. doi: 10.1016/j.fuel.2010.06.035.

Nonaka, M., Hirajima, T. and Sasaki, K. (2011) "Upgrading of low rank coal and woody biomass mixture by hydrothermal treatment," Fuel, 90(8), pp. 2578-2584. doi: 10.1016/j.fuel.2011.03.028.

Norton, G. A. (1993) "A review of the derivative thermogravimetric technique (burning profile) for fuel combustion studies," Thermochimica Acta, 214(2), pp. 171-182. doi: 10.1016/0040-6031(93)80053-D. 
Ohki, A., Xie, X.-F., Inakajima, T., Itahara, T. and Maeda, S. (1999) "Change in properties and combustion characteristics of an Indonesian low-rank coal due to hydrothermal treatment," Coal Preparation, 21(1), pp. 23-34. doi: $10.1080 / 07349349908945606$.

Pribadi, A. (2016) "Indonesian coal policy," in Workshop on CCS for AFOC member. Cirebo: Puslitbang Geologi Kelautan.

Racovalis, L., Hobday, M. and Hodges, S. (2002) "Effect of processing conditions on organics in wastewater from hydrothermal dewatering of low-rank coal1," Fuel, 81(10), pp. 1369-1378. doi: 10.1016/S0016-2361(02)00024-8.

Sahu, S. G., Sarkar, P., Chakraborty, N. and Adak, A. K. (2010) "Thermogravimetric assessment of combustion characteristics of blends of a coal with different biomass chars," Fuel Processing Technology, 91(3), pp. 369378. doi: 10.1016/j.fuproc.2009.12.001.

Sakaguchi, M., Laursen, K., Nakagawa, H. and Miura, K. (2008) "Hydrothermal upgrading of Loy Yang Brown coal Effect of upgrading conditions on the characteristics of the products," Fuel Processing Technology, 89(4), pp. 391396. doi: 10.1016/j.fuproc.2007.11.008.

Scaccia, S. (2013) "TG-FTIR and kinetics of devolatilization of Sulcis coal," Journal of Analytical and Applied Pyrolysis, 104, pp. 95-102. doi: 10.1016/j.jaap.2013.09.002.

Solomon, P. R., Serio, M. A., Carangelo, R. M., Bassilakis, R., Yu, Z. Z., Charpenay, S. and Whelan, J. (1991) "Analysis of coal by thermogravimetry-fourier transform infrared spectroscopy and pyrolysis modeling," Journal of Analytical and Applied Pyrolysis, 19, pp. 1-14. doi: 10.1016/0165-2370(91)80031-3.

Song, H., Liu, G., Zhang, J. and Wu, J. (2017) "Pyrolysis characteristics and kinetics of low rank coals by TG-FTIR method," Fuel Processing Technology, 156, pp. 454-460.

doi: 10.1016/j.fuproc.2016.10.008.

Umar, D. F. (2016) "Sifat pembakaran batubara hasil proses upgrading dengan teknologi hot water drying," in Santoso, B., Ardha, I. G. N., Umar, D. F., Rochani, S., Husaini, Madiutomo, R. M. N., Ningrum, N. S., Wahyudi, T., Damayanti, R., and Handayani, S. (eds.) Prosiding Kolokium
Puslitbang Teknologi Mineral dan Batubara 2016. Bandung: Puslitbang tekMIRA, pp. 49-61.

Umar, D. F., Daulay, B. and Usui, H. (2004) "Reducing moisture content by hot water drying method," in Proc. the 21st Annual International Pittsburg Coal Conference. Osaka, Japan.

Umar, D. F., Usui, H. and Daulay, B. (2005) "Effects of processing temperature of hot water drying on the properties and combustion characteristics of an Indonesian low rank coal," Coal Preparation, 25(4), pp. 313-322. doi: $10.1080 / 07349340500444554$.

World Energy Council (2016) World Energy Resources 2016. London: World Energy Council 2016. Available at: http://www.energycolombia.org/images/ PUBLICACIONES/PDF/Resources_Sho rtReport_.pdf.

Wu, J., Liu, J., Zhang, X., Wang, Z., Zhou, J. and Cen, K. (2015) "Chemical and structural changes in XiMeng lignite and its carbon migration during hydrothermal dewatering," Fuel, 148, pp. 139-144. doi: 10.1016/j.fuel.2015.01.102.

Wu, J., Wang, J., Liu, J., Yang, Y., Cheng, J., Wang, Z., Zhou, J. and Cen, K. (2017) "Moisture removal mechanism of lowrank coal by hydrothermal dewatering: Physicochemical property analysis and DFT calculation," Fuel, 187, pp. 242249. doi: 10.1016/j.fuel.2016.09.071.

Yu, J., Tahmasebi, A., Han, Y., Yin, F. and Li, X. (2013) "A review on water in low rank coals: The existence, interaction with coal structure and effects on coal utilization," Fuel Processing Technology, 106, pp. 9-20. doi: 10.1016/j.fuproc.2012.09.051.

Yu, Y., Liu, J. and Cen, K. (2014) "Properties of coal water slurry prepared with the solid and liquid products of hydrothermal dewatering of brown coal," Industrial \& Engineering Chemistry Research, 53(11), pp. 4511-4517. doi: $10.1021 / \mathrm{ie} 5000592$.

Yu, Y., Liu, J., Wang, R., Zhou, J. and Cen, K. (2012) "Effect of hydrothermal dewatering on the slurryability of brown coals," Energy Conversion and Management, 57, pp. 8-12. doi: 10.1016/j.enconman.2011.11.016. 
Evaluation of Combustion Behaviour for Indonesian Low-Rank Coal ... Datin F. Umar et al.

Zhan, X., Jia, J., Zhou, Z. and Wang, F. (2011) "Influence of blending methods on the cogasification reactivity of petroleum coke and lignite," Energy Conversion and Management, 52(4), pp. 1810-1814. doi: 10.1016/j.enconman.2010.11.009.
Zhang, Y., Wu, J., Wang, Y., Miao, Z., Si, C., Shang, X. and Zhang, N. (2016) "Effect of hydrothermal dewatering on the physicochemical structure and surface properties of Shengli lignite," Fuel, 164, pp. 128133. doi: 10.1016/j.fuel.2015.09.055. 
